\title{
PERBANDINGAN MODEL PEMBELAJARAN DISCOVERY LEARNING DAN PROBING PROMPTING TERHADAP KEAKTIFAN BELAJAR SISWA
}

\author{
Widya Destiyanti Adjie ${ }^{1}$, Nurmala $\mathrm{R}^{2}$ \\ ${ }^{1}$ Pendidikan Matematika, Universitas Borneo Tarakan \\ ${ }^{2}$ Jurusan Pendidikan Matematika, Universitas Borneo Tarakan \\ 1widyadestiyanti19@gmail.com \\ 2nurmala.r17@gmail.com
}

\begin{abstract}
This research is a quasi-experimental research (quasi experimental), which aims to look at the comparison of discovery learning models and probing prompting to the learning activities of class IX MTs DDI Tarakan students. The results of descriptive analysis before being treated with an average achievement of student learning activeness in experimental class 1 using discovery learning models is $30.34 \%$ and in experimental class 2 using probing prompting learning models is $27.17 \%$. For the average percentage of the two experimental classes are both in the less active category. Descriptive analysis results after being treated with an average achievement of student learning activeness in experimental class 1 using discovery learning models higher that is equal to $53.5 \%$ included in the active category of the experimental class 2 using the probing prompting learning model is $43,14 \%$ is in the inactive category. For the average achievement of all indicators of student learning activeness for experimental class 1 is higher than in ekaperimne 2 . So the discovery learning model is better than the probing prompting learning model for the learning activeness of class IX MTs DDI Tarakanstudents.
\end{abstract}

Keywords: Experiments, Discovery Learning Learning Model, Probing Prompting Learning Model, Student Learning Activity

\begin{abstract}
Abstrak
Penelitian ini merupakan penelitian eksperimensemu (quasi esperimental),yang bertujuan untuk melihat perbandingan model pembelajaran discovery learning dan probing prompting terhadap keaktifan belajar siswa kelas IX MTs DDI Tarakan. Hasil analisis deskriptifsebelum diberi perlakuan dengan rata-rata pencapaian keaktifan belajar siswa dikelas eksperimen 1 yang menggunakan model pembelajaran discovery learningadalah $30,34 \%$ dan pada kelas eksperimen 2 yang menggunakan model pembelajaran probing prompting adalah27,17\%. Untuk rata-rata persentase kedua kelas eksperimen tersebut sama-sama berada pada kategori kurang aktif. Hasil analisis deskriptif setelah diberi perlakuan dengan rata-rata pencapaian keaktifan belajar siswa dikelas eksperimen 1 yang menggunakan model pembelajaran discovery learninglebih tinggi yaitu sebesar53,5\%termasuk dalam kategori aktif dari pada kelas eksperimen 2 yang menggunakan model pembelajaran probing prompting adalah43,14\% termasuk dalam kategori kurang aktif.Untuk rata-rata pencapaian dari seluruh indikator keaktifan belajar siswa untuk kelas eksperimen 1 lebih tinggi dibandingkan pada kelas ekaperimne 2. Jadi, model pembelajaran discovery learning lebih baik dibandingkan model pembelajaran probing prompting terhadap keaktifan belajar siswa kelas IX MTs DDI Tarakan.
\end{abstract}

Kata Kunci: Ekperimen,Model Pembelajaran Discovery Learning, Model Pembelajaran Probing Prompting, Keaktifan Belajar Siswa

Cara Menulis Sitasi: Adjie, W. A., \& Nurmala. (2020). Perbandingan Model Pembelajaran Discovery Learning dan Probing Prompting terhadap Keaktifan Belajar Siswa. Mathematic Education and Aplication Journal,volume 2, no. 1, halaman 33-40.

Salah satu karakteristik matematika adalah mempunyai objek yang bersifat abstrak. Sifat abstrak ini menyebabkan banyak siswa mengalami kesulitan dalam matematika dan tidak aktif dalam pembelajaran. Pada saat siswa belajar secara aktif, siswa akan memiliki rasa ingin tahu terhadap 
sesuatu, misalnya dengan cara aktif bertanya. Keterlibatan siswa secara aktif dalam proses pembelajaran matematika sangat diperlukan, sehingga materi yang telah diajarkan akan lebih bermakna dan lebih dimengerti dengan mudah. Pada saat siswa belajar secara pasif, siswa mengalami proses tanpa ada pertanyaan, tanpa ada menyatakan pendapat dan tanpa ada daya tarik dalam pembelajaran.

Berdasarkan wawancara dengan guru mata pelajaran matematika yang dilaksanakan pada semester ganjil tahun ajaran 2018/2019 diketahui bahwa keaktifan belajar siswa di kelas IX MTs DDI Tarakan dalam mengikuti proses pembelajaran masih sangat kurang. Hal ini dibuktikan dengan masih kurangnya siswa berpartisipasi dalam proses pembelajaran dikelas sehingga masih cukup banyak siswa yang lebih memilih untuk berbicara dan bermain dengan temannya,tidak menanggapi pertanyaan guru, serta tidak mendengarkan arahan dari guru sehingga sangat mengganggu dalam proses pembelajaran dan membuat siswa tertinggal materi pelajaran yang akan berakikat siswa tersebut tidak memahami materi yang telah diajarkan dan tidak bisa mengerjakan soal latihan yang diberikan oleh guru.

Hal ini di perkuat dengan hasil observasi yang dilaksanakan di MTs DDI Tarakan kelas IXA dan kelas IX-B dengan jumlah 59 siswa pada saat proses pembelajaran, diantaranya: 1) siswa yang mengajukan pertanyaan kepada guru ialah sebanyak 33,898\% atau sebanyak 20 siswa, 2) siswa yang menjawab atau menanggapi pertanyaan dari guru ialah sebanyak 30,50\% atau sebanyak 18 siswa, 3) siswa yang mendengar arahan yang diberikan oleh guru ialah sebanyak 32,20\% atau sebanyak 19 siswa, 4) pada saat guru meminta siswa untuk mengerjakan soal didepan kelas sebanyak $22,03 \%$ atau sebanyak 13 siswa yang mau mengerjakan soal didepan kelas. Hasil rata-rata penilaian keaktifan siswa kelas IX yaitu 29,6575\% dengan kategori rendah.

Pembelajaran yang efektif adalah pembelajaran yang memberikan kesempatan belajar sendiri atau melakukan aktivitas sendiri. Keaktifan siswa dalam proses belajar dapat mengembangkan bakat serta dapat memecahkan permasalahan dalam kehidupan sehari-hari. Belajar aktif dapat ditandai dengan keaktifan siswa yang belajar secara fisik dan mental (Sardiman, 2016:100). perlu adanya model pembelajaran yang tepat dan sesuai untuk memusatkan dan menarik perhatian siswa agar turut aktif dalam proses pembelajaran. Berdasarkan karakteristik siswa kelas IX MTs DDI Tarakan, perhatian siswa akan berpusat pada proses pembelajaran saat dipilih dan langsung dihadapkan pada sebuah permasalahan serta saat siswa diberi kesempatan untuk terlibat dalam proses pembelajaran dengan pengalaman langsung. Menurut Shoimin(2016:128) model pembelajaran probing promptingdapat menarik dan memusatkan perhatian siswa melalui pemberian pertanyaan-pertanyaan kepada siswa. Dan menurut Illahi (2012: 70) didalam proses pembelajaran menggunakan model pembelajaran discovery learning, digunakan kegiatan dan pengalaman langsung. Kegiatan dan pengalaman tersebut akan lebih menarik perhatian siswa dan memungkinkan pembentukan konsepkonsep yang lebih bermakna. Oleh karena itu model pembelajaran yang diharapkan dapat 
mempengaruhi keaktifan belajar siswa adalah model pembelajaran probing prompting dan discovery learning.

Beberapa penelitian terkait telah dilakukan, diantaranya penelitian yang dilakukan oleh Siregar dan Mulyana (2016) dengan hasil penelitian yang menunjukkan bahwa nilai rata-rata aktivitas belajar siswa dari 69,40 meningkat menjadi 81,33 melalui penerapan model pembelajaran probing prompting. Selanjutnya penelitian yang dilakukan oleh Istiana dkk (2015) dengan hasil penelitian yang menunjukkan bahwa penerapan model pembelajaran discovery learning dapat meningkatkan aktivitas belajar siswa dari 37\% hingga mencapai 77,78\%. Kemudian penelitian yang dilakukan oleh Hanggara dan Alfionita (2015) dengan hasil penelitian yang menunjukkan bahwa pada model pembelajaran discovery learning dan probingprompting, siswa yang memiliki minat belajar tinggi memiliki hasil belajar yang lebih baik daripada siswa yang memiliki minat belajar rendah dan sedang.

Dengan melihat beberapa penelitian yang telah dilakukan sebelumnya, model pembelajaran Probung Prompting dan Discovery learningkeduanya mampu untuk mendongkrak keaktifan belajar siswa. Oleh karena itu, peneliti tertarik untuk melakukan penelitian tentang "Perbandingan model pembelajaran probing prompting dan discovery learning terhadap keaktifan belajar siswa kelas IX MTs DDI Tarakan".

\section{METODE}

Penelitian ini berupa penelitian eksperimen semu (quasi esperimental),pengambilan sampelmenggunakan teknik simple random sampling (sampel acak sederhana) dengan menggunakan desain penelitian Nonequivalent Control Group Design dengan kelas eksperimen I menggunakan model pembelajar discovery learning dan kelas eksperimen II menggunakan model pembelajaran probing prompting.Instrumen pengumpulan data yang digunakan dalam penelitian ini berupa lembar observasi keaktifan belajar siswa yang akan dinilai selama proses pembelajaran dengan bantuan 4 orang observer. Adapun teknik analisis data yang dilakukan yaitu sebagai berikut.

\section{Teknik Analisis Deskriptif}

Menurut Sugiyono (2018: 207) statistik deskriptif adalah statistik yang digunakan untuk menganalisis data dengan cara mendeskripsikan atau menggambarkan data yang telah terkumpul sebagaimana adanya tanpa bermaksud membuat kesimpulan yang berlaku untuk umum atau generalisasi. Pada penelitian ini, statistik yang digunakan dalam penskoran pengamatan keaktifan belajar siswa menggunakan capaian keaktifan belajar siswa dengan rumus sebagai berikut:

$$
\text { Persentasekeaktifan }(\%)=\frac{\text { jumlah indikator yang terpenuhi }}{\text { jumlah indikator keseluruhan }} \times 100 \%
$$

Sumber : Utami (dalam Sari, 2013) 
Selanjutnya data nilai keaktifan siswa tersebut dikategorikan dengan ketentuan sebagai berikut:

Tabel 1. Kategori Keaktifan Belajar Siswa

\begin{tabular}{|c|c|}
\hline Presentase & Kategori \\
\hline $75 \%-100 \%$ & Sangat Aktif \\
\hline $50 \%-74,99 \%$ & Aktif \\
\hline $25 \%-49,99 \%$ & Kurang Aktif \\
\hline $0 \%-24,99 \%$ & Sangat Kurang Aktif \\
\hline
\end{tabular}

Sumber : Arikunto (2010: 18)

\section{HASIL DAN PEMBAHASAN}

Pengambilan data dilakukan sebanyak empat kali pertemuan pembelajaran dikelas eksperimen 1 dan kelas eksperimen 2. Pada pertemuan pertama kelas eksperimen 1 dan kelas eksperimen 2 diajar dengan menggunakan model pembelajaran konvensional untuk mengambil data keaktifan belajar siswa sebelum diberi perlakuan. pada pertemuan kedua, ketiga dan keempat kelas eksperimen 1 diberikan perlakuan berupa model pembelajaran discovery learning sedangkan pada kelas eksperimen 2 diberi perlakuan berupa model pembelajaran probing prompting. Padapertemuan keempat dilakukan pengambilan data keaktifan belajar siswa setelah diberi perlakuan pada kelas eksperimen 1 dan kelas eksperimen 2. Adapun tingkatan keaktifan belajar siswa pada data pretest kedua kelas adalah sebagai berikut:

Tabel 2. Kategori Keaktifan Belajar Siswa Kelas Eksperimen 1 dan Kelas Eksperimen 2(pretest)

\begin{tabular}{|c|c|c|c|c|c|}
\hline \multirow{2}{*}{$\begin{array}{c}\text { Interval } \\
\text { Keaktifan (\%) }\end{array}$} & \multicolumn{2}{|c|}{ Kelas Eksperimen 1 } & \multicolumn{2}{c|}{ Kelas Eksperimen 2 } & \multirow{2}{*}{ Kategori } \\
\cline { 2 - 6 } & P & Persentase (\%) & F & $\begin{array}{c}\text { Persentase } \\
(\boldsymbol{\%})\end{array}$ & \\
\hline $75 \%-100 \%$ & 0 & 0 & 0 & 0 & Sangat Aktif \\
\hline $50 \%-74,99 \%$ & 4 & 21,1 & 2 & 9,5 & Aktif \\
\hline $25 \%-49,99 \%$ & 8 & 42,1 & 10 & 47,6 & Kurang Aktif \\
\hline $0 \%-24,99 \%$ & 7 & 36,8 & 9 & 42,9 & Sangat Kurang Aktif \\
\hline
\end{tabular}

Berdasarkan tabel di atas, keaktifan belajar siswa pada kelas eksperimen 1 dan kelas eksperimen 2 tidak ada siswa yang berada pada kategori sangat aktif. pada kelas eksperimen 1 sebesar 21,1\% atau 4 siswa yang berada pada kategori aktif, sebesar $42,1 \%$ atau 8 siswa yang berada pada kategori kurang aktif dan sebesar 36,8\% atau 7 siswa yang berada pada kategori sangat kurang aktif. Sedangkan pada kelas eksperimen 2 sebesar 9,5\% atau 2 siswa yang berada pada kategori aktif, sebesar 47,6\% atau 10 siswa yang berada pada kategori kurang aktif dan sebesar $42,9 \%$ atau 9 siswa yang berada pada kategori sangat kurang aktif.

Pada data pretest persentase indikator dengan perolehan persentase tertinggi di kelas eksperimen 1 adalah pada visual activities kegiatan saat siswa membaca materi yang disajikan oleh guru (misalnya dengan membuat catatan kecil atau menggaris bawahi) dengan persentase sebesar 
$84,21 \%$. Sedangkan persentase indikator tertinggi di kelas eksperimen 2 adalah pada listening activities kegiatan saat siswa mendengarkan materi yang sedang dijelaskan oleh guru (misalnya dengan menunjukkan respon dengan mengangguk saat memahami sesuatu atau tersenyum) dengan persentase sebesar 76,19\%. Dari keseluruan indikator, rata-rata persentase kelas eksperimen 1 ialah sebesar 30,34\% sedangkan pada kelas eksperimen 2 sebesar 27,17\%. Untuk rata-rata persentase kedua kelas eksperimen tersebut sama-sama berada pada kategori kurang aktif.

Berdasarkan hasil analisis tersebut dapat disimpulkan bahwa keaktifan belajar siswa pada kelas eksperimen 1 dan kelas eksperimen 2 memiliki kondisi awal yang sama sebelum diberi perlakuan. Artinya, keaktifan belajar siswa sebelum diberi perlakuan berada pada kondisi yang setara. Sehingga, untuk melihat lebih lanjut perbandingan model pembelajaran discovery learning dan probing prompting terhadap keaktifan belajar siswa kelas IX MTs DDI Tarakan dilakukan analisis lanjutan pada data posttest.

Adapun tingkatan keaktifan belajar siswa pada data posttest kedua kelas adalah sebagai berikut:

Tabel 3. Kategori Keaktifan Belajar Siswa Kelas Eksperimen 1 dan Kelas Eksperimen 2(posttest)

\begin{tabular}{|c|c|c|c|c|c|}
\hline \multirow{2}{*}{$\begin{array}{c}\text { Interval } \\
\text { Keaktifan (\%) }\end{array}$} & \multicolumn{2}{|c|}{$\begin{array}{c}\text { Kelas } \\
\text { Eksperimen 1 }\end{array}$} & \multicolumn{2}{|c|}{ Kelas Eksperimen 2 } & \multirow{2}{*}{ Kategori } \\
\cline { 2 - 5 } & $\mathbf{F}$ & $\begin{array}{c}\text { Persentase } \\
(\boldsymbol{\%})\end{array}$ & $\mathbf{F}$ & $\begin{array}{c}\text { Persentase } \\
(\boldsymbol{\%})\end{array}$ & \\
\hline $75 \%-100 \%$ & 2 & 10,5 & 1 & 4,76 & Sangat Aktif \\
\hline $50 \%-74,99 \%$ & 10 & 52,6 & 5 & 23,81 & Aktif \\
\hline $25 \%-49,99 \%$ & 7 & 36,9 & 13 & 61,91 & Kurang Aktif \\
\hline $0 \%-24,99 \%$ & 0 & 0 & 2 & 9,52 & Sangat Kurang Aktif \\
\hline
\end{tabular}

Berdasarkan tabel di atas, pada kelas eksperimen 1 dapat dilihat bahwa sebesar 10,5\% atau 2 siswa yang berada pada kategori sangat aktif, sebanyak 52,6\% atau 10 siswa yang berada pada kategori aktif, sebesar 36,9\% atau 7 siswa yang berada pada kategori kurang aktif dan tidak ada siswa yang berada pada kategori sangat kurang aktif..Sedangkan pada kelas eksperimen 2 sebesar 4,76\% atau 1 siswa yang berada pada kategori sangat aktif, sebanyak $23,81 \%$ atau 5 siswa yang berada pada kategori aktif, sebesar 61,91\% atau 13 siswa yang berada pada kategori kurang aktif dan sebesar $9,52 \%$ atau 2 siswa yang berada pada kategori sangat kurang aktif.

Pada data pretest persentase indikator dengan perolehan persentase tertinggi di kelas eksperimen 1 adalah pada visual activities kegiatan saat siswa membaca materi yang disajikan oleh guru (misalnya dengan membuat catatan kecil atau menggaris bawahi) dengan persentase sebesar 94,73\%. Sedangkan persentase indikator tertinggi di kelas eksperimen 2 adalah pada visual activities saat siswa mengamati hasil pekerjaan teman sekelompok saat diskusi, oral activities saat siswa bertanya kepada guru apabila tidak paham dengan materi yang diajarkan (misalnya dengan 
mengangkat tangan atau berdiri dan bertanya), dan listening activities kegiatan saat siswa mendengarkan materi yang sedang dijelaskan oleh guru (misalnya dengan menunjukkan respon dengan mengangguk saat memahami sesuatu atau tersenyum) dengan persentase yang sama yaitu sebesar 80,95\%. Dari keseluruan indikator, rata-rata persentase kelas eksperimen 1 lebih tinggi dari pada kelas eksperimen 2. Rata-rata persentase kalas eksperimen 1 ialah sebesar 53,5\% dengan kategori aktif sedangkan pada kelas eksperimen 2 sebesar 43,14\% dengan kategori kurag aktif. Untuk rata-rata persentase kedua kelas eksperimen tersebut sama-sama berada pada kategori kurang aktif.

Pada saat pembelajaran kelas eksperimen 1 diberi perlakuan dengan menggunakan model pembelajaran discovery learning. Pada pembelajaran ini siswa sendiri yang menyelesaikan permasalahan yang diberikan oleh guru. Dengan kata lain siswa mampu menemukan sendiri penyelesaian dari masalah tersebut. Guru memberikan kesempatan kepada siswa untuk mengumpulkan data dan informasi yang dibutuhkan seperti membaca literatur, melakukan wawancara serta melakukan uji coba sendiri. Selanjutnya siswa mampu mengolah informasi yang telah diperolehnya sampai memperoleh rumusan jawaban untuk menyelesaikan permasalahan yang diberikan oleh guru. Sehingga pada pembelajaran ini siswa lebih aktif dan pembelajaran tidak berpusat kepada guru sehingga siswa mampu berlatih menginterpretasikan ide-ide serta gagasan-gagasannya dalam menyelesaikan masalah.

Sedangkan pada kelas eksperimen 2 diberikan perlakuan dengan menggunakan model pembelajaran probing prompting. Pada pembelajaran ini siswa dituntut untuk aktif bertanya. Perhatian siswa terhadap pembelajaran lebih terjaga karena siswa selalu mempersiapkan jawaban sebab harus selalu siap jika tiba-tiba ditunjuk oleh guru. Namun pada saat menyelesaikan permasalahan yang diberikan oleh guru, siswa cenderung lebih bergantung kepada guru dan tidak aktif secara mandiri untuk menyelesaikan permalahan yang diberikan.

Berdasarkan pembahasan tersebut diketahui bahwa model pembelajaran discovery learnimg dan probing prompting sama-sama baik terhadap keaktifan belajar siswa. Namun pada perolehan skor dan rata-rata persentase, skor dan rata-rata persentase keaktifan belajar siswa yang menggunakan model pembelajaran discovery learning lebih baik dari pada skor dan rata-rata persentase siswa yang menggunakan model pembelajaran probing prompting. Sehingga dapat disimpulkan bahwa keaktifan belajar siswa yang menggunakan model pembelajaran discovery learning lebih baik dibandingkan keaktifan belajar siswa yang menggunakan model pembelajaran probing prompting.

\section{KESIMPULAN}

Berdasarkan hasil analisis dan pembahasan mengenai perbandingan model pembelajaran discovery learnng danprobing prompting terhadap keaktifan belajar siswa kelas IX MTs DDI Tarakan diperoleh kesimpulan bahwa pada model pembelajaran discovery learning persentase tertinggi terdapat pada visual activities saat siswa membaca materi yang disajikan oleh guru dengan persentase sebesar 94,73\%. Keaktifan belajar siswa dengan menggunakan model pembelajaran discovery 
Perbandingan Model Pembelajaran Discovery Learning dan Probing Prompting terhadap Keaktifan Belajar 39 Siswa. Adji, \& Nurmala

learning dengan rata-rata persentase kelas sebesar 53,3\% berada pada kategori aktif. Sedangkan pada model pembelajaran probing prompting persentase tertinggi terdapat pada visual activities saat siswa mengamati hasil pekerjaan teman sekelompok saat diskusi, oral activities saat siswa bertanya kepada guru apabila tidak paham dengan materi yang diajarkan, dan listening activities saat siswa mendengarkan materi yang sedang dijelaskan oleh guru dengan persentase yang sama yaitu $80.95 \%$. Keaktifan belajar siswa dengan menggunakan model pembelajaran probing prompting dengan ratarata persentase kelas sebesar $43,14 \%$ berada pada kategori kurang aktif. Berdasarkan rata-rata persentase tersebut dapat dikatakan bahwa model pembelajaran discovery learning lebih baik dibandingkan model pembelajaran probing prompting terhadap keaktifan belajar siswa kelas IX MTs DDI Tarakan.

\section{DAFTAR PUSTAKA}

Arikunto, Suharsimi. 2010. Prosedur Penelitian Suatu Pendekatan Praktik. Jakarta: Rineka Cipta.

Hanggara, Yudhi dan Vina Alfionita. 2015. Eksperimentasi Model pembelajaran Probing Prompting dan Discovery Learning Terhadap Hasil Belajar Matematika Ditinjau Dari Minat Belajar Siswa Kelas VII SMP Negeri 3 Batam. Jurnal Pythagoras Vol. 4 No. 2. Dari https://journal.unrika.ac.id/index.php/jurnalpythagoras/article/view/188. Diakses pada tanggal 17 Februari 2019.

Illahi, Mohammad Takdir. 2012. Pembelajaran Discovery Strategy \& Mental Vocational Skill. Yogyakarta: Diva Press.

Istiana, Galuh Arika, Agung Nugroho Catur S dan J.S Sukardjo. 2015. Penerapan Model Pembelajaran Discovery Learning untuk meningkatkan Aktivitas dan Prestasi Belajar Pokok Bahasan Larutan Penyangga Pada Siswa Kelas XI IPA Semester II SMA Negeri 1 Ngemplak Tahun Pembelajaran 2013/2014. Jurnal Pendidikan Kimia Vol. 4 No. 2. Dari https://jurnal.fkip.uns.ac.id/2012/index.php/kimia/article/view/5709. Diakses pada tanggal 24 Februari 2019.

Sardiman, A.M. 2016. Interaksi dan Motivasi Belajar Mengajar. Jakarta: Rajawali Press.

Sari, Denis Puranama dan Rustanto Rahardi. 2013. Peningkatan Keaktifan dan Hasil Belajar Siswa Kelas XI IPS 2 SMA Negeri 1 Turen Pada Pokok Bahasan Turunan Dengan Pembelajaran Kooperatif Tipe Teams Games Turnament (TGT). https://jurnalonline.um.ac.id/data/artikel. Diakses pada 16 Agustus 2019 
Shoimin, Aris. 2016. 68 Model Pembelajaran Inovatif Dalam Kurikulum 2013. Yogyakarta: Ar-Ruzz Media.

Siregar, Lukmanul Hakim dan Rachmat Mulyana. 2016. Penerapan Model Pembelajaran Probing Prompting untuk meningkatkan Aktivitas dan Hasil Belajar Siswa Pada Mata Pelajaran Konstruksi Bangunan Di Kelas X Program Keahlian Teknik Gambar Bangunan SMK Negeri 1 Stabat. Jurnal Education Buuilding Vol. 2 No. 1. Dari https://jurnal.unimed.ac.id/2012/index.php/eb/article/view/3741. Diakses pada tanggal 24 Februari 2019.

Sugiyono. 2018. Metode Penelitian Kuantitatif, Kualitatif dan $R \&$ D. Bandung: Alfabeta. 